\title{
Rancang Bangun Aplikasi Online untuk Berita dan Kegiatan Esports
}

\author{
Tirza Artahsasta, Departemen Ilmu Komputer, Universitas Pelita Harapan Kampus Surabaya, \\ Andreas, Departemen Ilmu Komputer, Universitas Pelita Harapan Kampus Surabaya, dan \\ Hartarto Junaedi, Departemen Sistem Informasi, Institut Sains dan Teknologi Terpadu Surabaya
}

\begin{abstract}
Abstrak-Tema esports tidak asing lagi bagi dunia. Kegiatan bermain game yang awalnya hanya hiburan telah berkembang menjadi kompetisi hingga menjadi karir. Indonesia pun tidak tertinggal dan dapat bersaing dengan pemain dari seluruh dunia. Untuk dapat mencapai tahap itu tentu dibutuhkannya wadah pemain pemula untuk bertanding dan berlatih. Sangat jarang ditemui di Indonesia wadah untuk pemain menengah kebawah atau turnamen kecil yang menerima peserta dengan nama tim yang terkenal. Diharapkan dengan penelitian ini dapat menambah wadah untuk pemain pemula dan meningkatkan prestasi esports di Indonesia. Sistem ini dibuat untuk mengatasi kurangnya efisiensi dan efektivitas dalam pengiklanan, pendaftaran serta transaksi yang diperlukan untuk pengadaan event esports. Dalam sistem ini juga terdapat proses yang mengolah data agar pengguna lebih mudah memahami dan menganalisa. Mengurangi peluang penipuan transaksi dengan melakukan transaksi di dalam sistem yang diamati langsung oleh admin serta alamat transaksi resmi yang dicantumkan pada sistem. Berdasarkan hasil uji coba yang dilakukan, dapat disimpulkan bahwa dengan adanya sebuah aplikasi website esports dapat mempermudah penyampaian informasi kepada pelanggan dan alur pengiklanan, pendaftaran serta transaksi menjadi lebih teratur. Sistem ini memudahkan admin mengatur data berita serta data event yang akan diadakan, sedang berjalan dan sudah selesai. Selain itu dengan sistem pengolah data dapat juga memudahkan admin memantau aktifitas yang terjadi serta kondisi website dari waktu ke waktu.
\end{abstract}

Kata Kunci- Event, Portal Esports, Turnamen.

\section{Pendahuluan}

$\mathrm{Z}$ aman sekarang teknologi yang sudah maju membuat para generasi muda tidak lagi mencari permainan di luar rumah namun hanya dengan komputer dan smartphone sudah bisa mendapatkan hiburan permainan, baik yang dimainkan secara perorangan maupun bersama-sama. Tidak hanya generasi muda, game online sudah dikenali dan dimainkan semua umur terutama melalui smartphone. Game

Oktober 2020

Tirza Artahsasta, Departemen Ilmu Komputer, Universitas Pelita Harapan Kampus Surabaya, Surabaya, Jawa Timur, Indonesia (e-mail: tirza.asasta@gmail.com)

Andreas, Departemen Ilmu Komputer, Universitas Pelita Harapan Kampus Surabaya, Surabaya, Jawa Timur, Indonesia (e-mail: andreas.jodhinata@uph.edu)

Hartarto Junaedi, Departemen Sistem Informasi, Institut Sains dan Teknologi Terpadu Surabaya, Surabaya, Jawa Timur, Indonesia (e-mail: hartarto.j@gmail.com) online merupakan hiburan yang dapat menghilangkan rasa stress namun hal tersebut tentu saja memiliki pengaruh baik dan buruk.

Pengaruh buruk game online adalah ketika seseorang kecanduan bermain game online. Berita mengenai pengaruh buruk game online yang merusak generasi jaman sekarang banyak ditemui di website maupun siaran berita di televisi, dari kesehatan mental sampai kesehatan fisik. Hal tersebut tentu saja membuat game online merupakan hal yang perlu dihindari karena para orang tua menghawatirkan anakanaknya menjadi korban pengaruh buruk tersebut.

Namun tentu saja tidak semua game online memberikan pengaruh buruk, ada juga prestasi yang dapat diraih oleh para gamer online. Pertanyaannya adalah apakah wadah untuk menampung prestasi dan bakat anak-anak tersebut sudah memadai? Salah satu wadah prestasi tersebut adalah tournament esports. Tournament esports sudah cukup populer dan sampai tingkat internasional. Seiring berjalannya perkembangan teknologi, tournament esports bisa dilakukan secara online tanpa harus berkumpul disuatu tempat tertentu.

Di Indonesia, pemerintah juga menyadari bahwa dibutuhkannya wadah untuk prestasi bidang esports dengan mengadakan Piala Presiden. Masyarakat yang menyukai esports dan mau mengikuti perlombaan belum tentu mengetahui perihal Piala Presiden tersebut. Peserta yang mengikuti Piala Presiden merupakan pemain yang sudah kelas atas dan kelompok yang sudah terkenal di Indonesia. Para pemain yang masih belum sampai ke tahap tersebut kesulitan mencari wadah berprestasi di bidang esports.

Sangat jarang ditemui situs mengenai tournament esports. Di Indonesia sudah ada beberapa web yang dapat kita temui contohnya, metindonesia.co.id, esportsnesia.com, esports.id. Dari web yang telah disebutkan, informasi yang ditampung memudahkan masyarakat untuk terus update di dunia esports. Namun yang menjadi permasalahan adalah turnamen untuk kelas menengah ke bawah sangat sulit ditemui.

Web esports di Indonesia masih memiliki kekurangan yaitu adanya beberapa halaman yang tidak bisa dibuka dan sebagian besar hanya menampung berita. Pengiklanan mengenai tournament esports sangatlah minim. Ada yang menampung iklan join tournament esports namun kebanyakan tidak bisa dibuka dan informasi yang ditampung tidak cukup jelas. Kurangnya keseimbang antara berita dan 
event tournament menyebabkan masyarakat tidak mendapatkan wadah yang cukup untuk berprestasi.

Dalam penelitian ini terdapat beberapa masalah yang harus dihapadi dalam proses pembuatannya. Berikut adalah rumusan masalah dalam penelitian ini:

1) Bagaimana cara membuat website dengan User Interface yang menarik dan tidak membingungkan user?

2) Bagaimana membedakan penggunaan website sebagai customer atau admin dengan tujuan halaman yang berbeda dan aktifitas yang berbeda? Login sebagai admin atau customer.

3) Bagaimana cara membuat database yang baik dan benar sehingga proses transaksi dan pengecekan tidak mendapati masalah?

4) Bagaimana tiap user dapat bergabung pada suatu event dalam waktu yang ditentukan dengan memanfaatkan pengaturan waktu pada website untuk penjadwalan?

5) Bagaimana cara membatasi satu user bergabung event sesuai kapasitas peruser? Misalnya, satu user hanya boleh daftar satu kali pada event tersebut atau boleh mendaftar dua kali pada event tersebut.

6) Bagaimana admin dapat mengatur event yang akan datang dan berita yang terbaru? Termasuk create, update dan delete.

Dengan dibuatnya penelitian ini, ada tujuan yang ingin dicapai. Berikut adalah tujuan yang akan dicapai dalam penelitian ini:

1) Menampung berita mengenai esports dari berbagai sumber agar user dapat terus mengikuti perkembangan berita yang ada.

2) Membuat event yang terjadwal dan memiliki persyaratan sesuai kebutuhan event yang dapat di cek secara sistem.

3) Memudahkan admin mengatur event yang akan datang dan berita terbaru dengan sistem yang sudah disediakan.

4) Memudahkan masyarakat mendaftar event secara online yang dicek secara otomatis untuk beberapa ketentuan.

\section{ESPORTS}

Pada tanggal 19 Oktober 1972, 24 mahasiswa berkumpul di Stanford University's Artificial Intelligence Laboratory untuk bertempur didalam game yang merupakan salah satu video game pertama di dunia yaitu Spacewar. Hadiah utamanya yang direbutkan adalah satu tahun berlangganan Rolling Stone magazine. Spacewar dimainkan pada Programmed Data Processor-1 yang merupakan komputer awal yang beratnya 1.200 pounds dan jumlahnya terbatas pada pusat akademik. Spacewar diciptakan oleh sekelompok mahasiswa dari Massachusetts Institute of Technology.

Kompetisi selalu menjadi bagian utama dari video game. Contohnya pada tempat bermain arcade, beberapa orang yang mendapat skor tertinggi dapat menuliskan namanya dengan kombinasi tiga huruf untuk pamer ke pemain berikutnya sampai ada yang bisa mengalahkan skor mereka. Source code game Spacewar dirilis secara gratis, tetapi saat video game menjadi perusahaan komersial, developer melihat potensi dari persaingan formal merupakan cara yang menarik untuk mendapatkan lebih banyak pelanggan.
Pada tahun 1980, Atari mengadakan Space Invaders Championship yang diikuti oleh ribuan pemain yang berkompetisi. Pada tahun berikutnya disiarkan acara kompetisi starcade di televisi. Pada tahun 1990, diadakan Nintendo World Championships yang menjadi tempat memamerkan keterampilan peserta bermain Super Mario. Pembuatan game menjadi semakin kompleks, mendukung naiknya jumlah pemain dan grafis serta sistem menjadi semakin bagus. Persaingan yang meningkat di internet melahirkan komunitas berupa forum yang merumuskan dan menyebarkan strategi di seluruh dunia.

Empat decade kemudian, kompetisi dalam video game atau biasa dikenal sebagai olahraga elektronik yaitu esports, telah menjadi fenomena dunia. Jutaan orang menonton kompetisi setiap bulannya dan diadakannya pelatihan full time untuk berkompetisi merebutkan hadiah uang tunai yang mencapai jutaan. Gamer profesional memiliki jersey tim serta perlengkapan bermain yang bermerek. Competitive team games merupakan judul yang paling populer di tahun 2016 dimana permainan tidak hanya membutuhkan kemampuan yang hebat namun juga dibutuhkannya komunikasi dan koordinasi, biasanya terdiri dari lima pemain dalam satu tim. Bukan hanya bermain, tim profesional harus dapat mengelola emosi, keuangan dan fokus tim.

Perkembangan game telah menjadi budaya dan kekuatan ekonomi. Berdasarkan penelitian dari Newzoo, industri video game memiliki pendapatan lebih dari \$100 miliar pada tahun 2017 dan esports mendapatkan bagian yang lebih besar dari investasi tiap harinya. Deloitte memproyeksikan bahwa pendapatan esports pada tahun 2016 mencapai \$500 juta.

Video game merupakan produk komersial. Biasanya terdapat satu perusahaan yang bertanggung jawab atas pengembangan suatu game besar, dengan sebagian besar memperoleh keuntungan finansial dari popularitas game tersebut. Tetapi pengembang bukanlah penyelenggara turnamen atau operator liga dan hanya beberapa perusahaan yang memiliki permainan berkelanjutan sebagai esports.

Potensi esports sangat besar. Meskipun masih kalah dengan olahraga tradisional, yang diperkirakan pendapatan aktivitas keuangan esports mencapai \$278 juta pada tahun 2015 menurut Newzoo, dibandingkan dengan pendapatan lebih dari \$10 miliar untuk NFL dan \$21 miliar untuk liga sepak bola Eropa. Penonton kejuaraan liga game League of Legends mencapai 32 juta pada tahun 2013, dibandingkan dengan 120 juta pemirsa yang menonton Super Bowl 2015.

Esports adalah permainan video game yang bersifat kompetitif. Apakah esports adalah olahraga? Akan terlihat tidak masuk akal jika melihat dari satu sudut pandang dimana pemain hanya bermain dengan keyboard dan mouse Tubuh tidak terlihat bergerak selain jari-jari dan pikiran. Video game memiliki sifat yang kompetitif dan membutuhkan teknik serta strategi tertentu sama seperti olahraga lain yang membutuhkan mental dan pikiran, contohnya catur. Semua olahraga akan disiarkan di ESPN yang menjadi wasit Amerika tentang apa saja yang termasuk dalam golongan olahraga. Pada tahun 1990, ESPN2 menyiarkan kompetisi permainan Magic: The Gathering 
yaitu collectible card game yang pertama dimana pemain bertempur dengan memanggil makhluk-makhluk fantasi dan melemparkan mantra seperti Lightning Bolt dan Lava Exe yang diwakili oleh kartu-kartu.

Pada tahun 2016 ESPN meluncurkan bagian kusus untuk esports di situsnya. Bagian yang menghambat dalam pertumbuhan esports adalah ketakutan akan hal baru. Permainan hanya hadir dalam beberapa dekade dibanding dengan sejarah olahraga yang sudah ribuan tahun seperti lintasan, lapangan atau renang. Tetapi game sudah memiliki sejarah puluhan tahun yang siap untuk terus dikembangkan. Esports bukanlah sekedar kompetisi melainkan sebuah karir. Karir pada bidang esports cukup menjanjikan dan berpotensi. Contohnya seorang pro gamer Dota 2 bernama KuroKy yang berhasil membawa pulang hadiah sebesar $\$ 10,000,000$ bersama timnya di kompetisi The International 2017.

Profesi sebagai atlet esports mengharuskan pemain untuk tergabung ke dalam sebuah tim sebelum mengikuti turnamen yang dimulai dari kelas amatir. Atlet esports profesional biasanya memiliki agen yang akan membantu dirinya mendapatkan kontrak dan penawaran. Sama seperti tim olahraga pada umumnya, anggota tim diwajibkan untuk berlatih dan bertanding. Didalam tim juga memiliki manager yang bertugas membangun brand dari sebuah tim, mengatur kontrak pemain, mencari bakat baru dan bertanggung jawab mengkoordinasi secara keseluruhan. Sebuah tim juga memiliki pelatih yang bertugas mengamati pemain dan lawan di setiap pertandingan untuk menganalisa kekuatan dan kelemahan serta mengatur perkembangan strategi yang dipakai oleh tim. Organisasi tim serta para pemain yang mengubah permainan video game menjadi lebih dari sekedar hiburan, juga menjadi salah satu kunci yang membantu publikasi kepada masyarakat yang lebih luas mengenai permainan kelas atas atau turnamen-turnamen besar.

Banyak berita beredar di Indonesia mengenai game online. Berita-berita yang baik dan buruk membuat pro kontra orang tua yang memperbolehkan dan tidak memperbolehkan anaknya bermain game. Salah satu contoh berita buruk yang dikutip dari website resmi berita di Indonesia yaitu berita pada website liputan6 menuliskan bahwa seorang bocah $\mathrm{Xu}$ Tianci berumur 13 tahun tewas akibat jatuh dari lantai empat gedung apartemen yang menjadi tempat tinggalnya. Ibu dari Xu Tianci mempercayai bahwa penyebab kematian anaknya adalah game PUBG yang membuat $\mathrm{Xu}$ berpikir bahwa dia dapat melakukan halhal yang dilakukan seperti pada karakter game tersebut. Xu diketahui tengah bermain game PUBG sebelum ia meninggal. Ibu $\mathrm{Xu}$ juga banyak menerima kritik dari pengguna jejaring media sosial mengenai ibu yang lalai menjaga anaknya dan tidak memberikan perhatian yang cukup. Kritikan masyarakat pun di sanggah oleh ibu dan memberikan peringatan untuk meningkatkan kesadaran tentang masalah ini sehinggga tidak ada lagi korban lain.

Sifat game yang bisa membuat para pemain kecanduan hingga lupa diri membuat banyak orang tua memandang game merupakan dampak negatif bagi anak-anak mereka. Sebagai orang tua pasti akan memarahi anaknya jika mengetahui anaknya seorang gamer. Itulah penyebab utama kerusakan komunikasi hubungan antara gamer dan orang tua. Komunikasi yang terganggu akan membuat orang tua susah mengenali anaknya dan susah memantau apa yang di alami anaknya. Cara terbaik yang dapat dilakukan oleh orang tua adalah untuk tidak memarahi maupun melarang melainkan mengajak anaknya menceritakan tentang game yang ia mainkan. Dengan begitu hubungan komunikasi antara orang tua dan anak akan terjalin dengan baik dan orang tua pun memiliki kesempatan untuk mengoreksi pemahaman anaknya. Anak membutuhkan dampingan orang tua untuk membentuk mental yang baik dan menjadikan game dampak positif bagi mereka.

Di Indonesia tidak semua berita mengenai esports dan game merupakan berita buruk. Indonesia juga tidak kalah bersaing dalam hal esports melawan negara-negara lain. Salah satu contoh berita membanggakan yang dikutip dari website resmi berita di Indonesia yaitu berita pada website indosport menuliskan bahwa dua atlet esports PUBG asal Indonesia yang disoroti oleh media asing karena prestasinya yang membanggakan pada PUBG Mobile World League 2020 East. Indonesia memiliki dua perwakilan yang dikirim untuk mengikuti PMWL 2020 East yaitu Bigetrob eSports dan Morph Team yang telah bermain pada Opening Weekend turnamen PMWL 2020 East pada hari Minggu 12 Juli 2020. Dari hasil pertandingan kemarin dua pemain dari Bigetron eSports menjadi sorotan media asing yaitu Sportskeeda. Selain dua pemain tersebut, terdapat tiga pemain lagi asal Indonesia yang masuk kedaftar pemain dengan kill terbanyak di PMWL 2020 East. Dua tim asal Indonesia ini akan bertanding sampai akhir turnamen yang akan dimulai pada tanggal 14 Juli hingga 2 Agustus 2020.

\section{ANALISA SISTEM}

Tema esports tidaklah mungkin lepas dari internet sehingga aplikasi yang menampung informasi dan perlombaan secara online merupakan salah satu penambahan wadah bagi para pemain esports untuk mengasah kemampuan dan mencari pengalaman. Dengan adanya aplikasi ini berharap dapat meningkatkan pengaruh baik dan mengurangi pengaruh buruk dari esports dalam masyarakat. Aplikasi ini dibuat agar masyarakat dapat lebih mudah mengikuti perkembangan esports didunia dan pendaftaran event menjadi lebih teratur dan cepat. Bagi admin yang mengatur isi dari aplikasi dan jalannya sistem pertandingan akan lebih teratur dan meminimalis kesalahan.

Untuk menggunakan aplikasi ini, customer baru perlu mendaftarkan diri sedangkan admin baru akan didaftarkan oleh admin lain yang bertugas mengurus user admin. Customer yang telah terdaftar harus mengaktifkan akunnya melalui email yang telah diberikan. Jika belum mengaktifkan akun maka customer tidak dapat login kedalam aplikasi. Hal ini berfungsi untuk menghindari customer yang mendaftar dengan email palsu atau salah memasukkan email pada saat mendaftar. Email digunakan untuk mengirimkan informasi penting terkait dengan pendaftaran event, pembayaran, dan penerimaan hadiah.

Customer yang mau mengikuti event dapat langsung mendaftar dan mengisi form persyaratan yang sudah 
disediakan. Setelah selesai mengisi form, customer akan menerima invoice dan detail pemesanan pada aplikasi. Pembayaran customer akan di cek manual oleh admin dengan cara customer meng-upload foto bukti pembayaran dengan format image kedalam form pembayaran yang telah disediakan. Data bukti pembayaran akan masuk kedalam detail pemesanan customer dan dikirim ke email yang terdaftar pada customer. Admin akan menerima email mengenai bukti pembayaran dan memeriksa bukti pembayaran yang sudah di upload oleh customer melalui aplikasi. Jika pembayaran dinyatakan lunas oleh admin maka customer akan menerima notifikasi mengenai pembayaran berhasil melalui email dan diberikan nomor peserta.

Pertandingan akan otomatis dimulai sesuai tanggal main yang telah dicantumkan pada event details. Saat pertandingan selesai maka admin akan menentukan pemenang dan customer sebagai pemenang akan menerima notifikasi bahwa telah memenangkan pertandingan melalui email. Form review akan diberikan kepada seluruh customer yang menjadi peserta dan ucapan terima kasih telah berpartisipasi. Admin bertugas untuk mengirimkan hadiah kepada customer pemenang dengan cara meng-upload foto bukti hadiah dengan format image kedalam form pemberian hadiah yang telah disediakan. Setelah admin berhasil mengisi form, customer akan mendapat notifikasi bahwa hadiah telah dikirimkan dan foto bukti tersebut pada email pemenang.

Pada sistem customer terdapat my ticket yang berisi event yang telah diikuti maupun yang sedang diikuti. Hal ini berperan sebagai laporan untuk customer, sedangkan admin memiliki bentuk laporan yang berbeda. Pada sistem admin terdapat library yang memiliki filter untuk melihat pendapat, pengeluaran, jumlah customer yang telah mengaktifkan akun dan jumlah customer yang telah mengikuti event. Admin juga dapat melihat data mengenai customer yang telah aktif atau belum aktif dan customer yang telah di non-aktifkan oleh admin. Pada setiap tabel pada halaman admin diberi fasilitas sorting dan search untuk mempermudah admin mencari informasi yang diperlukan.

Penggambaran proses dua entitas yang mengakses dashboard sesuai kebutuhan masing-masing dapat dilihat pada gambar 1. Berikut penjelasan mengenai dua entitas yang memiliki fungsi dan peran yang berbeda:

1) Admin berperan sebagai pengelola data news, event, dan user yang terdiri dari admin dan customer. Admin juga dapat memeriksa bukti pembayaran dari customer, meminta laporan dari sistem, dan mengirimkan hadiah pemenang dalam bentuk foto bukti transfer bank. User admin diregisterkan oleh admin yang bertugas mengatur user. Setelah menerima email informasi akun baru, admin dapat login kedalam akun barunya sesuai dengan informasi yang telah diterima.

2) Customer berperan sebagai peserta atau pelanggan yang dapat mendaftar event yang telah dibuat oleh admin. Customer juga dapat membaca news yang telah dimasukkan oleh admin, melihat daftar event details yang telah diikuti, mengirim bukti pembayaran dengan meng-upload bukti transfer bank dalam bentuk foto, mengirim review terhadap event yang diikuti, dan mengelola akun user yang dimiliki masing-masing customer.

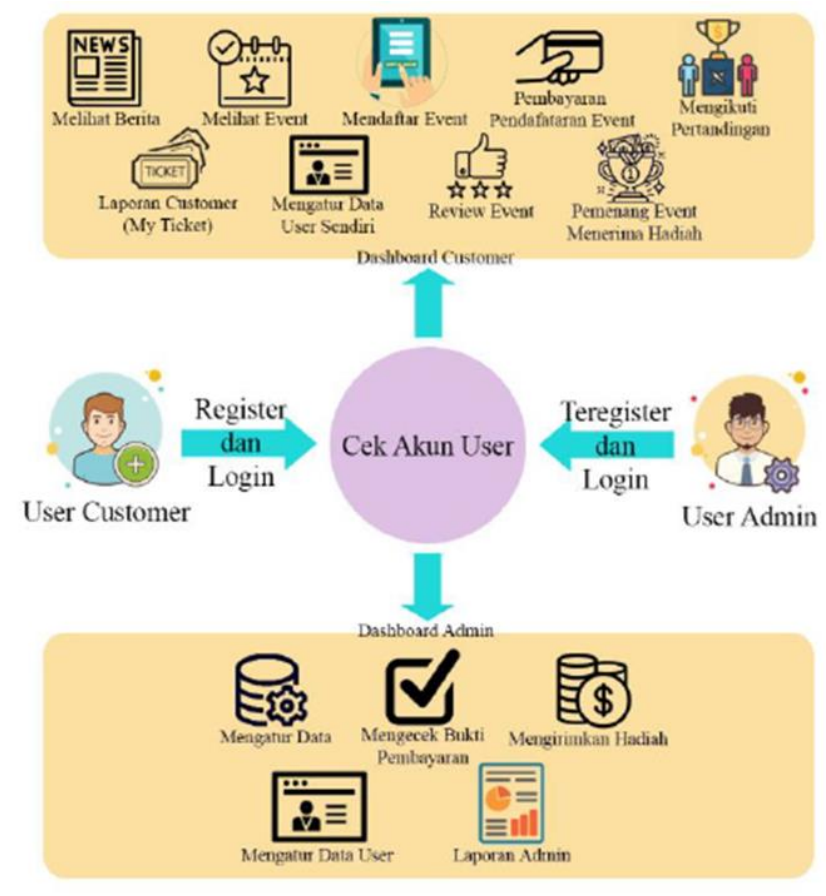

Gambar. 1. Diagram Proses Mengakses Dashboard Sesuai Akun User

\section{IMPLEMENTASI PROGRAM}

\section{A. Home}

Halaman home merupakan halaman pertama yang diakses oleh user saat membuka website Victorem. Fitur yang ditampilkan pada halaman home yaitu quotes dari Victorem untuk menarik customer agar melihat fitur yang disediakan, informasi yang disediakan yaitu event dan news, konten terakhir yang di-upload oleh admin dan poster tim utama penyusun bisnis Victorem.

\section{B. Register dan Login}

Halaman register merupakan halaman yang digunakan oleh customer untuk mendaftarkan diri agar memiliki user untuk login. Halaman ini diakses melalui modal login dengan menekan tombol sign up. Modal login dapat diakses dengan menekan tombol login/register. Fitur yang ditampilkan pada halaman ini yaitu form register. Tampilan website untuk halaman register dapat dilihat pada Gambar 4.4 Halaman Register. Customer akan diberi pemberitahuan untuk mengaktifkan akun melalui email yang telah dikirimkan setelah berhasil melakukan registration. Customer dapat melakukan login setelah mengaktifkan akunnya.

\section{Event}

Halaman event merupakan halaman yang pertama diakses saat menekan tombol event atau view event pada menu yang disediakan. Pada halaman ini akan ditampilkan semua event yang ada dengan dibagi tampilannya menjadi lima event tiap halaman. Setiap event memiliki halaman event details yang 
menampung seluruh informasi yang perlu diketahui customer mengenai event tersebut. Customer yang ingin mendaftar harus mengisi form untuk ketentuan pendaftaran event. Customer dipastikan untuk login terlebih dahulu sebelum mendaftar.

Event ditampilkan berdasarkan urutan statusnya yaitu open, postponed, full, closed, started, prize, done dan canceled, lalu diurutkan berdasarkan waktu pada setiap statusnya. Untuk mengaplikasikan sistem pengurutan tersebut dibutuhkan elemen SQL yang digunakan untuk memanggil data dari database. Elemen SQL yang digunakan adalah The SQL CASE Statement. Untuk penggunaan elemen SQL pada Codeigniter yang mengaplikasikan sistem pengurutan event berdasarkan status dan waktu dapat dilihat pada gambar 2 .

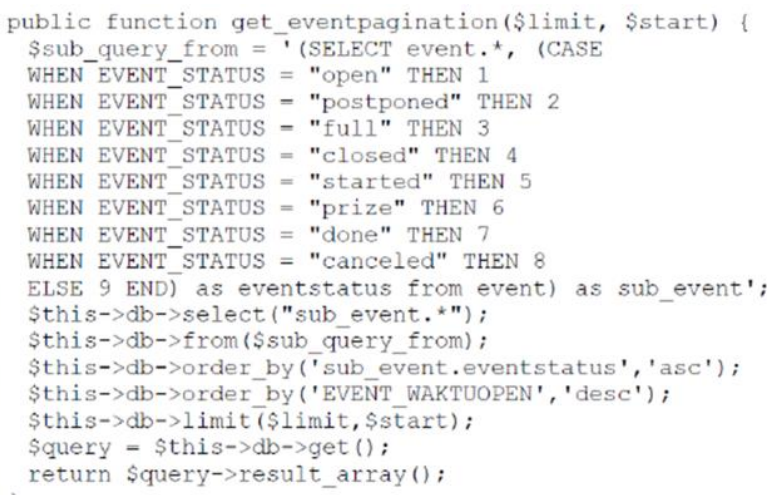

Gambar. 2. Segmen Program Pengurutan Event Berdasarkan Status dan Waktu

\section{My Ticket}

Halaman my ticket merupakan halaman yang menampung seluruh ticket yang dimiliki oleh customer yang sedang login. Pada halaman ini akan ditampilkan semua ticket yang ada dengan dibagi tampilannya menjadi lima ticket tiap halaman. Tiap ticket memiliki halaman ticket details yang menampung seluruh informasi ticket yang perlu diketahui oleh customer dan tiap ticket baru perlu dilakukan pembayaran sebelum tanggal ticket akan hangus. Informasi akan diberikan kepada ticket yang sudah melakukan pembayaran, penerimaan hadiah dan review. Saat ticket berhasil melakukan pengumpulan pembayaran maka customer yang membayar dan admin akan menerima email pemberitahuan bahwa pengumpulan pembayaran telah berhasil dilakukan lalu customer akan dialihkan ke halaman pemberitahuan berhasilnya pengumpulan pembayaran dan harus menunggu konfirmasi dari admin. Ticket yang sudah selesai bertanding akan diberi form review yang perlu diisi customer. Customer akan dialihkan ke halaman hasil review setelah berhasil mengisi dan mengumpulkan review.

\section{E. News}

Halaman news merupakan halaman pertama yang diakses saat customer menekan tombol news atau view news pada menu yang disediakan. Pada halaman ini akan ditampilkan semua news yang ada dengan dibagi tampilannya menjadi enam news tiap halaman. Untuk news yang bersumber dari
Victorem sendiri tidak diberi tombol go to source. Tiap news memiliki halaman read news yang menampilkan isi dari news yang dipilih. Fitur search news yang ada di sebelah tombol login atau tombol username customer menampilkan halaman dengan news yang sesuai dengan keyword pada judulnya.

\section{F. Contact}

Halaman contact merupakan halaman yang diakses jika customer menekan tombol contact pada menu yang disediakan. Pada halaman ini akan ditampilkan informasi tentang Victorem yaitu about, sosial media, address, phone, email, ID Line, peta lokasi dan poster tim utama penyusun bisnis Victorem.

\section{G. User Settings}

Halaman user settings dapat diakses dengan menekan tombol yang menampilkan username customer yang sedang login. Halaman ini digunakan customer untuk mengubah informasi pada user yang diperbolehkan untuk diubah. Customer dapat mengubah fullname dan email pada halaman account settings. Customer dapat memperbarui password pada halaman change password.

\section{H. Home Admin}

Halaman home admin hanya dapat diakses oleh admin dengan cara login user admin menggunakan modal login yang ada pada halaman home. Halaman ini menampung informasi penting yaitu overview aktifitas website, income, outcome dan table payment submitted yang hanya menampilkan sepuluh data terbaru.

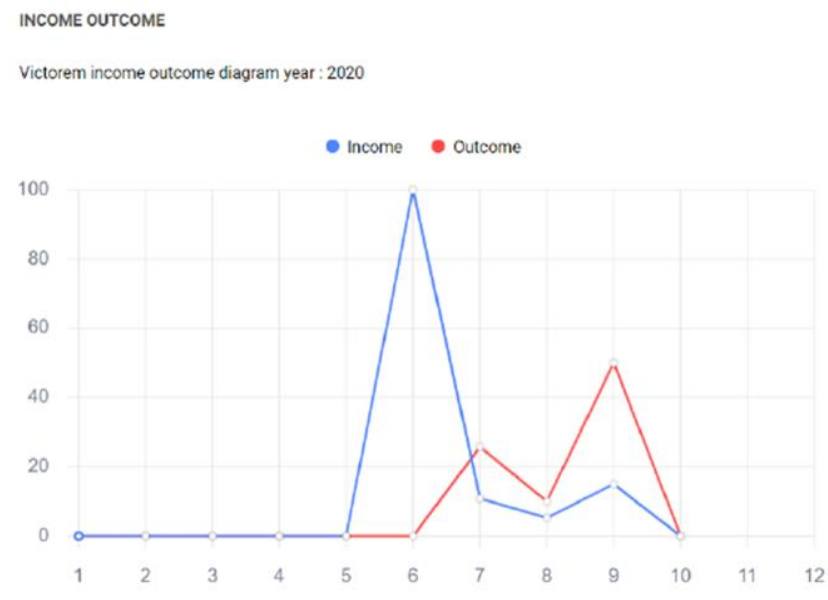

Gambar. 3. Chart Income dan Outcome pada Halaman Home Admin

Pada halaman ini, terdapat chart yang menampilkan income dan outcome dalam persen. Tampilan chart dapat dilihat pada gambar 3. Pembuatan chart dengan framework Codeigniter diperlukan pengolahan data yang dilakukan didalam file PHP yang ada pada controllers dan menampilkan data yang sudah diolah didalam file PHP yang ada pada views. Segmen program untuk pengolahan data dapat dilihat pada gambar 5 dan segmen program untuk menampilkan data yang sudah diolah dapat dilihat pada gambar 4 


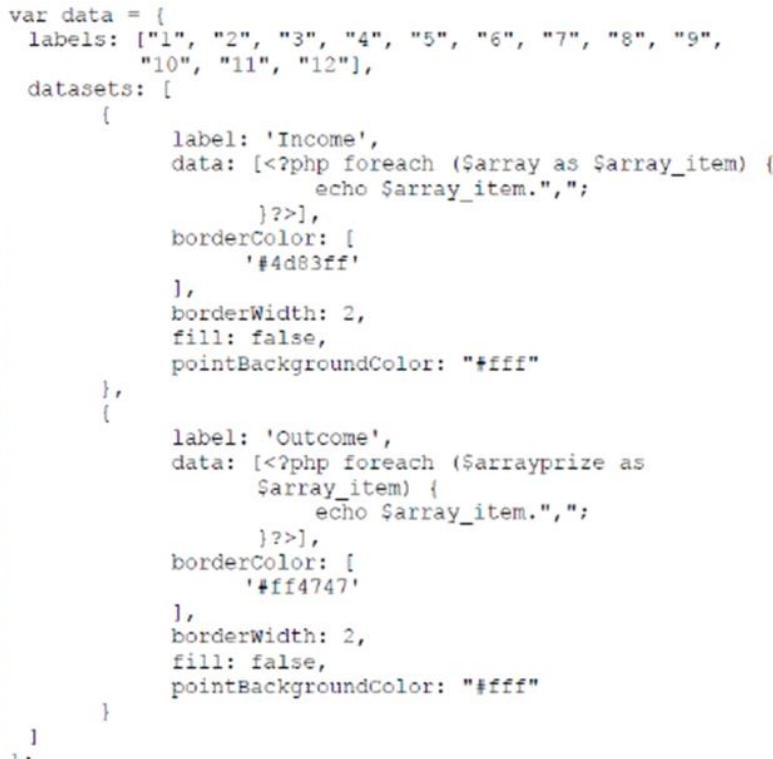

Gambar. 4. Segmen Program untuk Menampilkan Data

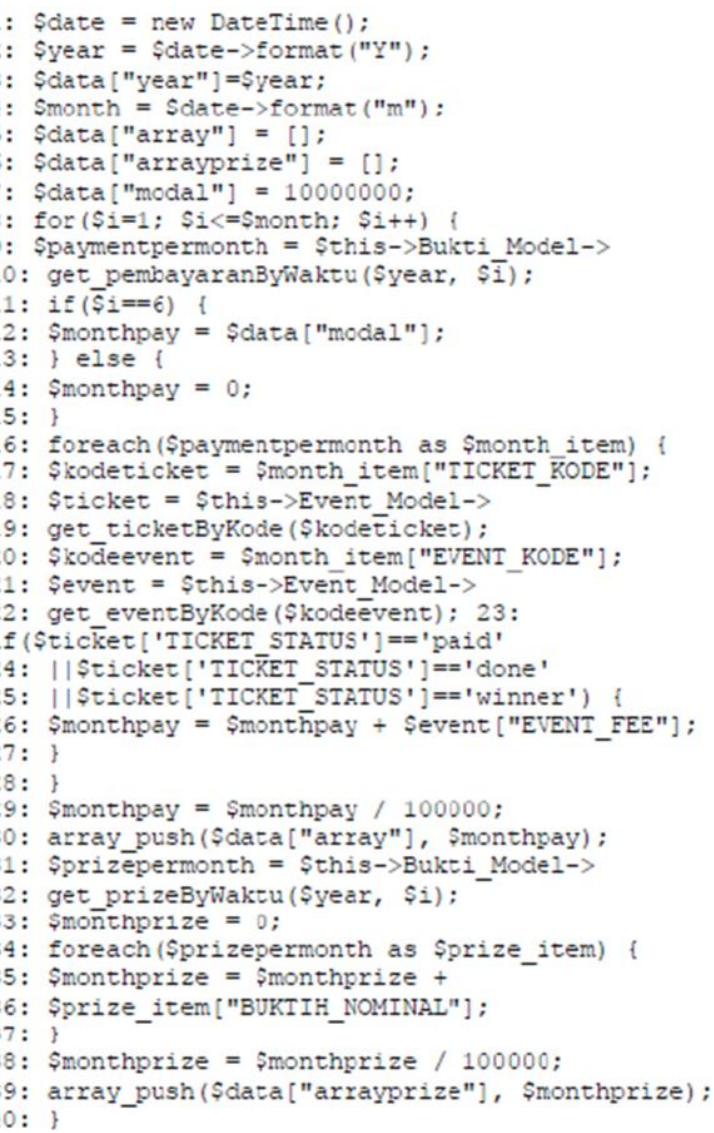

Gambar. 5. Segmen Program untuk Pengolahan Data

\section{Event Admin}

Event admin merupakan fitur yang digunakan admin untuk mengurus data event. Menu event memiliki pilihan berbentuk dropdown menu yaitu new event dan event list. Halaman new event digunakan admin untuk membuat event baru dan pemberitahuan berhasil atau tidaknya pembuatan event baru akan diberi keterangan pada tampilan form yang sama.
Event yang sudah dibuat oleh admin akan ditampilkan pada halaman event list. Setiap event pada event list memiliki menu detail yang berfungsi untuk mengakses halaman event details. Event yang ada pada list dengan kondisi belum memilliki peserta yang mendaftar dapat diubah dengan memilih menu edit dan dibatalkan.

Event yang belum dimulai dapat diundur sedangkan event yang sudah mulai dapat dinyatakan selesai dan admin harus menentukan pemenang. Event yang sudah selesai akan menampilkan pilihan send prize to winner untuk mengakses halaman form bukti hadiah yang perlu dikirim ke pemenang, prize details untuk mengakses halaman yang menampung informasi mengenai pengiriman hadiah pemenang dan review list untuk mengakses tabel review event yang dipilih. Customer akan menerima email pemberitahuan jika memenangkan event dan menerima hadiah.

\section{J. Ticket}

Halaman ini menampung informasi mengenai seluruh ticket yang ada. Digunakan admin untuk melihat ticket yang ada dilengkapi dengan fitur sorting dan search.

\section{K. Payment}

Halaman ini menampung informasi mengenai seluruh pembayaran yang telah dilakukan customer. Digunakan admin untuk melihat pembayaran yang ada, mengkonfirmasi pembayaran dan melihat informasi lengkap pada halaman payment details. Pembayaran yang memiliki status waiting atau menunggu konfirmasi memiliki tombol check pada dropdown menu action sedangkan pembayaran lain yang tidak sedang menunggu konfirmasi memiliki tombol details pada dropdown menu action. Customer akan menerima pemberitahuan melalui email mengenai pembayaran yang telah dikonfirmasi atau ditolak. Customer yang pembayarannya ditolak harus memperbarui pembayaran.

\section{News Admin}

News admin merupakan fitur yang digunakan admin untuk mengurus data news. Menu news memiliki pilihan berbentuk dropdown menu yaitu new news dan news list. Halaman new news digunakan untuk membuat news baru. News yang sudah dibuat oleh admin akan ditampilkan pada halaman news list. Setiap news pada news list memiliki menu detail yang berfungsi untuk mengakses halaman news details, menu edit yang berfungsi untuk mengubah informasi news yang sudah ada dan menu delete yang berfungsi untuk menghapus news yang sudah ada.

\section{New Admin}

Fitur ini berfungsi untuk menambahkan user admin baru. Admin yang dapat mengakses fitur ini adalah admin yang memiliki bidang kusus yaitu bidang admin sedangkan admin yang memiliki bidang lain tidak dapat mengakses fitur ini. Admin baru akan menerima email pemberitahuan bahwa dirinya telah terdaftar menjadi admin.

\section{N. User}

User merupakan fitur yang digunakan admin untuk mengurus user yang ada. Fitur ini digunakan oleh admin yang memiliki bidang admin untuk mengurus user 
sedangkan admin yang memiliki bidang lain hanya dapat melihat data yang disediakan. Menu user memiliki pilihan berbentuk dropdown menu yaitu admin list dan customer list. Admin dengan bidang admin dapat melakukan user settings kepada semua user admin, delete atau menonaktifkan user admin dan delete atau menon-aktifkan user customer. User yang sudah dinon-aktifkan dapat di-recover atau diaktifkan kembali.

\section{O. About}

Halaman ini menampung informasi mengenai about Victorem. Admin dengan bidang admin dapat mengubah data about yang sudah ada. Untuk admin dengan bidang yang lain hanya dapat melihat data about yang tersedia.

\section{P. User Settings Admin}

Fitur ini digunakan admin untuk mengatur informasi pada user miliknya sendiri. Fitur ini memiliki dua halaman yaitu halaman account settings untuk mengubah fullname maupun email dan halaman change password untuk mengubah password.

\section{KESIMPULAN}

Kesimpulan yang didapat setelah melalui proses pengembangan website esports. Berikut adalah tujuh kesimpulan dari pengembangan sistem website esports:

1) Website ini dapat mempermudah pelanggan mengikuti perkembangan dunia game serta membuka wawasan pelanggan dengan berita-berita seputar game yang disediakan. Dengan adanya fitur search pada bagian berita dapat mempermudah pelanggan mencari berita dengan kata kunci yang diinginkan. Pelanggan juga dapat mengakses website yang merupakan sumber dari berita tertentu.

2) Website ini dapat mempermudah pelanggan mengikuti event yang sudah disediakan. Dapat mengetahui berbagai informasi mengenai event memudahkan pelanggan mendaftar tanpa perlu bertanya kepada admin. Pendaftaran dapat dilakukan langsung oleh pelanggan tanpa perlu menghubungi admin.

3) Website ini dapat mempermudah admin mengatur event. Dengan waktu yang sudah ditentukan, event dapat close registration secara otomatis. Ketentuan registrasi juga lengkap sesuai dengan form yang disediakan sehingga tidak ada pelanggan yang mendaftar dengan informasi yang kurang lengkap.

4) Website ini dapat menjamin keamanan transaksi pelanggan. Pelanggan tidak akan mengalami penipuan dari pihak yang mengaku sebagai admin karena sistem pembayaran di dalam aplikasi dijamin aman. Pembayaran yang dilakukan dijamin aman karena akun bank yang menerima transaksi sudah ditulis jelas oleh admin tanpa perlu lagi bertanya ke pihak manapun yang bisa saja mengaku sebagai pihak admin.

5) Website ini dapat mempermudah pelanggan memantau kegiatan yang telah dilakukan. Setiap event yang diikuti akan tercatat jelas. Penerimaan hadiah untuk pemenang, review dan pembayaran yang dilakukan pelanggan juga tercatat didalam informasi event masing-masing.
6) Website ini dapat mempermudah admin memantau transaksi. Setiap transaksi yang masuk dari pelanggan akan diberi pemberitahuan melalui email. Seluruh transaksi yang terjadi juga tercatat jelas sehingga admin tidak akan kehilangan data transaksi yang sudah terjadi.

7) Website ini dapat mempermudah admin memantau hasil dari keseluruhan aktivitas. Disediakan fitur laporan yang menghitung jumlah pemasukan dan pengeluaran tiap bulannya, pelanggan yang telah mengikuti event, jumlah hadiah yang telah dikirim, berita yang telah dibuat serta user pelanggan yang aktif.

\section{DAFTAR PUSTAKA}

[1] Roland Li. (2017, September 5). Good Luck Have Fun: The Rise Of eSports. [Online]. Available: https://books.google.co.id/books/about/ Good_Luck_Have_Fun.html?id=gF2CDwAAQBAJ\&printsec=frontc over\&source $=k p \_r e a d \_b u t t o n \&$ redir_esc $=\mathrm{y} \# \mathrm{v}=$ onepage $\& \mathrm{q} \& \mathrm{f}=\mathrm{false}$

[2] T. L. Taylor. (2012, March 23). Raising The Stakes: E-Sports and The Professionalization of Computer Gaming. [Online]. Available: https://books.google.co.id/books?id=CiL8aPrSeKcC\&printsec=frontc over\# $\mathrm{v}=$ onepage $\& \mathrm{q} \& \mathrm{f}=\mathrm{false}$

[3] E-book Esportsnesia. (2020, January 28). Literasi Esports. [Online]. Available: https://drive.google.com/file/d/1vUp5iQ3LD2UI28Zu3w L1sWEFp1x-GWSV/view

[4] Immanuela Harlita Josephine. (2018, September 5). Akibat Kecanduan Gim PUBG, Bocah 13 Tahun Tewas Mengenaskan. [Online]. Available: https://www.liputan6.com/citizen6/read/3637237/akibat-kecanduangim-pubg-bocah-13-tahun-tewas-mengenaskan

[5] Mohammad Khalid Syihabuddin. (2020, July 14). Prestasi 2 Atlet eSports PUBG Indonesia Disorot Media Asing. [Online]. Available: https://www.indosport.com/esports/20200714/prestasi-2-atlet-esportspubg-indonesia-disorot-media-asing

Tirza Artahsasta lahir di Surabaya, Jawa Timur pada tahun 1999. Menyelesaikan pendidikan di SD Kristen Petra 10 Surabaya pada tahun 2011. Menyelesaikan pendidikan di SMP Kristen Petra 1 Surabaya pada tahun 2014. Menyelesaikan pendidikan di SMA Kristen Petra 1 Surabaya pada tahun 2017. Menyelesaikan kuliah di Universitas Pelita Harapan Surabaya Campus pada tahun 2020 dengan Program Studi Strata Satu Sistem Informasi, Fakultas Ilmu Komputer. 